\title{
The Measurement of Media Literacy Skill of Indonesian Language Teachers Based on Individual Competence
}

\author{
Santi Pratiwi Tri Utami ${ }^{1}$, Wati Istanti ${ }^{2}$, Nurlaili Irias Putri ${ }^{3}$ \\ \{1 santi_pasca@mail.unnes.ac.id, ${ }^{2}$ istanti_unnes@yahoo.co.id, ${ }^{3}$ nurlailiiriasp@gmail.com\} \\ ${ }^{1,2,3}$ State University of Semarang
}

\begin{abstract}
The media saturated era demands the education circle, including Indonesian language teachers not only being able to operate the media, but also being critical of the content within it. At this time, there are $25 \%$ of Indonesian language teachers who have media literacy skills. The measurement of individual competence-based media literacy skill aims to measure the level of one's ability in using and utilizing the media. The measurement methodology based on two categories of measurement standards; namely the level of personal competence and social competence. The conclusion of this conceptual study is media literacy will be implemented in teaching and learning process of Indonesian subjects. Therefore, the level of literacy skill of Indonesian language teachers needs to be known for sure. One of them is to make sure the conduciveness of language skill learning, which is vital in the demand of $21^{\text {st }}$ Century skills and reference of Higher Order Thinking Skills (HOTS) for students.
\end{abstract}

Keywords: Media Literacy, Individual Competence, Indonesian Subjects

\section{Introduction}

The development of information and technology is a necessity for the education circle, especially for teachers. At the moment, Indonesia has entered the media saturated era, an era in which mass media has been progressing rapidly. This development can be seen in the terms of medium and content. This condition requires professional teachers not only be able to operate the media, but also to be critical of the content within it.

The era shift also creates a tendency for teachers to access digital media (internet, social media, smart phones, etc.) and begin to leave conventional media (television, radio, handie talkie, etc.) [1]. Especially for digital media, there were more than one trillion internet sites that can be accessed easily. A very large number is certainly proportional to the increase amount of information. It needs to be aware because not all of information gives a positive effect for our education.

For professional teachers, the government urged that teachers should be awake about media literacy. As reported by edukasi.kompas.com on December 12, 2017, there were $25 \%$ of teachers who had media literacy skills. From this minimal amount, it is known that most of 
them have only mastered the scope of proficiency limited to learning media. In fact, the scope of media literacy is very broad, including in contributing to the spread of hoax.

cnnindonesia.com on June 8, 2018 released a statement by Muhammad Ridwan, Head of the Public Relations Bureau of the State Personnel Agency (BKN), who received an official complaint that 6.4 million user accounts who were work as State Civil Apparatus (ASN), for example teachers, were hoax spreader. This amount represented the number of professional accounts as the most hoax spreader in Indonesia. It is indeed an irony to think the main task of the teacher as an activator and the spearhead of literacy activities in the world of education.

The era of new media literacy has been dominated and even been ingrained. Therefore, it is necessary media literacy skills aim to 1) "empowered" in the middle of exposure to such a massive flow of information, 2) protect the negative impact of the media, and 3) change the perspective of life integrally to be more adaptive to change.

The measurement of individual competence-based media literacy skill is the development of the concept of the new media literacy individual framework. The measurement concept of individual competence essentially measures one's ability to use and utilize the media. Among others, the ability to use, produce, analyze, and communicate the message through the media. Individual competence measures media literacy skill based on two measurement standard categories that are the level of personal competence and social competence. As for 1) personal competence is a one's ability to use the media and analyze the media content and 2) social competence is a one's ability to communicate and make social relations through the media and be able to produce the media content.

Media literacy is implemented in teaching and learning process of all subjects, including Indonesian language. Based on preliminary studies, Indonesian language teachers, especially for Junior High or High School tend to be passive in using digital media. Even though they are very dominant in using digital media in the learning process, especially in accessing text modelling.

This is in accordance with the pattern of Indonesian-based learning curriculum revision in 2016, which uses text-based learning patterns. Therefore, from now on the Indonesian language teachers are in need text modelling. Usually, they are looking for and using the internet modeling. Then, some of them arrange variations of text modeling from the internet. One of them is to make sure the conduciveness of language skill learning, which is vital in the demand of $21^{\text {st }}$ century skills and reference of Higher Order Thinking Skills (HOTS) for students.

Studies on media literacy have been carried out by several researchers, namely Kleemans and Gonnie Eggink (2018), Hobbs (2003), Ashley (2013), Ptaszek (2018). Kleemans' research [2] aims to empower youth in the media era which develops rapidly. This research was conducted on 1300 high school students in the Netherlands. They started a media literacy program to find out the level of student literacy in news content. The research indicators used are the level of teacher and age. The results of the study conclude there are opportunities for improvement to improve the task of media literacy in all school links in the Netherlands.

Hobbs [3] analyzed the critical ability of $11^{\text {th }}$ grade students in reading text. The results showed media literacy instruction improved students' ability to identify, main ideas in written media, audio and visual media. Statistically, there are significant differences between the quantity and quality of writing. Other conclusions state that specific text analysis skills have also improved, including the ability to identify goals, target audience, point of view, the construction techniques used in media messages, and the ability to identify information omitted from news media broadcast in written format, audio or visual. 
Ashley's research [4] aims to develop and assess measurement scales that focus specifically on critical news media literacy. The measurement scale of media literacy conceptualizes it based on content assessment, constructs, and predictive validity. The study was conducted on students with significant predictors of knowledge about topic in the news, which indicated that the need for a broader framework. Meanwhile, Ptaszek [5] stated that the measurement process used multistage model. The results of the study stated that the success of media literacy measurement depends on the selection method and the proper measurement tool. The nature of media literacy measurement is usually quantitative in the form of selfassessment (conducted on a small group of respondents).

This research provides a novelty in terms of the scale of measurement of media literacy and measured respondents. The studies referred to previously used more conventional measurement scales and measured respondents were students and college students. This study uses a measurement scale for new literacy media with individual competence scale and measured respondent is Indonesian language teacher.

\section{Research Method}

Professional teacher is teacher who has ability and special expertise in the field of teacher training, so that he is able to carry out his duty and function as a teacher with maximum ability. Professional teacher is teacher who is well-educated and trained, and has a lot of experience in his field [6].

As a professional job, the teacher is a profession that has special requirement, such as 1) requires skill based on in-depth concept and theory of science, 2) emphasis on a particular field of expertise in accordance with the profession, 3) requires an adequate level of teacher education, 4) there is sensitivity to the social impact of the work carried out, 5) has a strong commitment to not only transform knowledge, but also to the effort of individual character formation that can be the principal for the formation of national character.

Teachers as professional at work also need to refer to the principle of teacher professionalism that has been assigned in Law No. 14 of 2005 chapter III article 7, namely 1) have a talent, interest, find oneself and idealism; 2) have a commitment to improve the quality of education, faith, piety and noble character; 3 ) have academic qualifications and educational background in accordance with the field. In his profession, professional teacher not only take the task of knowledge transfer, but also need to instill values and norms of the students, incuding behavior in new media literacy.

Understanding the role of teacher, especially Indonesian language teachers, is very complex in this digital era. The swift flow of information from new media makes the role of Indonesian language teachers seem to be minimalist. However, Indonesian language teachers should participate in the current of technological development to explore intelligently, instead of going to fall the situation. Professional Indonesian language teachers must be able to take advantage the energy of a large new media, both as individual and activator of the literacy movement, including media literacy activities [7].

Media literacy is a series of media movement, namely media literacy movement that is designed to increase individual control toward the media they use to send and receive message [8]. The same thing was explained by the [9], which stated that media literacy was the ability to access, analyze, and evaluate the meaning of image, sound, message encountered in daily life and was an important part of contemporary culture, and to communicate well on media 
used personally. The most common component of media literacy is the awareness of many media messages and the critical ability in analyzing and questioning is seen, read, and watch [10]. In the current era of information disclosure, the growth of new media has improved significantly. Penetration of new media type has penetrated into various circles without distinguishing social and economic strata, including teachers. The use of new media has shifted to lifestyle. In a sense, the new media has taken a role in important parts of life of Indonesian language teachers. New media has had an influence on public in various ways. Therefore, there is a conclusion that society cannot be separated from digital technology anymore. Onslaught of information is very diverse now, needs to be balanced with the ability of media literacy as a cultural talisman for the negative impact that is very likely to appear. In addition, media literacy also aims to protect consumer who is vulnerable and weak information on the impact of new media penetration.

\section{Results And Discussion}

The initial concept of individual competence was done by the European Commission in the final report study on assessment criteria for media literacy level in 2009. Previously, this framework has been extensively used to measure level of media literacy in European countries.

Individual competence is a one's ability to use and utilize the media [11]. Including the ability to use, produce, analyze, and communicate the message through the media. Individual competence consists of two categories, namely 1) Personal Competence, one's ability to use the media and analyze the media content, 2) Social Competence, one's ability to communicate and build social relations through media and be able to produce media content [12].

Personal competence consists of technical skills and critical understanding. Moreover, The Social Competence consists of communicative abilities. The following are the detail of the concept of individual competence [13].

A. Technical Skill is the ability of individual to access content and operates the media.

Technical Skill consists of three indicators, namely:

1. Computer and internet skill. (Rate 20\%)

2. Balanced and active use of media. (Rate $50 \%$ )

3. Advanced internet use. (Rate $30 \%$ )

B. Critical Understanding is the ability to analyze and evaluate the media content comprehensively. Critical Understanding consists of three indicators, namely:

1. Understanding media content and its functioning. (Rate $30 \%$ )

2. Knowledge about media and media regulation. (Rate $40 \%$ )

3. User behavior. (Rate 30\%)

C. Communicative Abilities is the ability to socialize and participate through the media and produce the media content. Communicative Abilities consists of 3 three indicators, that are:

1. Social relations. (Rate $20 \%$ )

2. Citizen participation. (Rate $50 \%$ )

3. Media creation. (Rate $30 \%$ )

Each component in individual competence has different rate in measuring media literacy abilities. Here are the details. 
Table I Assessment Rate of Individual Competence

\begin{tabular}{clc}
\hline No & \multicolumn{1}{c}{ Aspect } & Rate \\
\hline 1. & Personal Competence & $77 \%$ \\
& a. Technical Skill & $67 \%$ \\
& b. Critical Understanding & $33 \%$ \\
2. & Sosial Competence & $23 \%$ \\
\cline { 2 - 2 } & a. Communicative Abilities & $100 \%$ \\
\hline
\end{tabular}

After knowing the rate of each component of the literacy assessment to analyze the results of the calculation of the questionnaire and combine it with the rate of each component. The results of the questionnaire calculation will be the basic for categorizing the level of media literacy, namely basic, medium, and advanced.

Table 2. Level of Media Literacy Skills

\begin{tabular}{cclc}
\hline No & Skill Level & \multicolumn{1}{c}{ Description of Skill } & Indicator Value \\
\hline 1 & Basic & $\begin{array}{l}\text { The ability to operate the media is not too high, the } \\
\text { ability to analyze the media content is not really good, } \\
\text { and the ability to communicate through the media is } \\
\text { limited. }\end{array}$ & $<70$ \\
2 & Medium ability to operate the media is quite high, the \\
ability to analyze the media content is quite good, and \\
is active in communicating through the media. \\
The ability to operate the media is very high, the \\
ability to analyze the media content is very in-depth, \\
and is very active in communicating through the \\
media.
\end{tabular}

The concept of media literacy is the ability to access media and respond to media messages critically. This is done to improve individual's control toward the media used. The object of media literacy studies are more directed at high school students and college students. Naturally, considering the development of information technology did occur during the era of their generation. In addition, the concern of many people will abuse and misunderstanding of the content presented by digital information media is also very high. The age and emotional level of high school students and college students have not guaranteed their ability in counteracting various bad effects that are very likely to arise in utilizing digital media. Moreover, the results of several studies indicate that there is still low level of their media literacy. Measurement of the level of media literacy at the educational level should not only be carried out on students' objects only. Teachers as subject also need to know the level of media literacy, especially Indonesian language teachers. As a defender of science, Indonesian subject is the spearhead of students' critical understanding. Therefore, the ability of media literacy of Indonesian language teachers is expected to be qualified and support the delivery of material. During this time, their media literacy ability is only limited to mastery of aspects of the medium, not to reach the content aspect.

Measurement of the level of media literacy based on individual competence will be able to explore the scale of media literacy abilities of Indonesian language teachers in terms of personal competence and social competence. From two aspects of the measurement scale, there will be obtained three levels of ability quantitatively. These abilities are technical skills, critical understanding, and communicative abilities. The percentage of measurement based on individual competence put the aspect of personal competence higher in rate than social competence. 
Technical skill refers to the basic abilities of Indonesian language teachers, including computer program that is mastered, what website or application is used, part of newspapers used for learning, provision of Internet quota for learning. Critical understanding refers to the ability of media literacy which include the types of text that are most easily understood when reading newspapers, website needed to support learning, what newspapers that support learning, TV station that support learning, rules or ethics in using digital content in learning, how to use reference sources in learning, and how to check the validity of reference sources. The communicative abilities refer to what social network is used to communicate with students through the internet and what content is shared by utilizing the internet network.

In general, the level of media literacy is divided into three categories namely basic, medium and advanced. The level of literacy of Indonesian language teachers is expected to be at a medium category. In this category the ability to operate the media is quite high, the ability to analyze the media content is quite good, and is active in communicating through the media. The ability of media literacy is minimal in the medium category will be a big capital in operating and utilizing the swift flow of information as learning material, in addition to being proficient in implementing it.

\section{Conclusion}

The conclusions of this conceptual study below the development of information and technology needs to be responded positively and critically, both in terms of the medium and its contents. The literacy media skill of the Indonesian language teachers are not only implemented in learning media, in a wide range even as a preventative measure for the hoax spreader. Indonesian language teachers, who are proficient in media literacy, contributed a great deal to teach wise behavior in using the media to students.

As a measurement, individual competence not only refers to how to use the media but also how to utilize the media. Personal competence and social competence become measurement criteria with technical skill, critical understanding, and communicative abilities. Skill level of medium becomes the minimum standard of media literacy level for Indonesian language teachers.

\section{References}

[1] J. C. CASTRO, "Learning and Teaching Art Through Social Media," Stud. Art Educ., vol. 53, no. 2, pp. 152-169, 2012.

[2] M. Kleemans and G. Eggink, "The impact of media literacy education on teenagers' news literacy," Journal. Educ., vol. 5 PS, no. iss. 1, pp. 74-88, 2016.

[3] R. HOBBS and R. FROST, "Measuring the acquisition of media-literacy skills," Read. Res. Q., vol. 38, no. 3, pp. 330-355, 2003, doi: 10.1598/rrq.38.3.2.

[4] S. Ashley, A. Maksl, and S. Craft, "Developing a news media literacy scale," Journal. Mass Commun. Educ., vol. 68, no. 1, pp. 7-21, 2013, doi: 10.1177/1077695812469802.

[5]＼cjkstart宋争辉, “No Title专业外语有屁用,”信阳师范学院, vol. 10, no. 2, pp. 1-15, 2018.

[6] W. Handayani and N. Emilda, "Pedagogi estetik melalui batik cianjur," pp. 116-120, 2018.

[7] K. Yuniar, A. Rakhmawati, B. Setiawan, and K. Saddhono, "Quantum Learning Methods to Improve students' speech skill using Javanese's Krama Alus,” in Journal of Physics: Conference Series, 2019, vol. 1339, no. 1, p. 12074.

[8] galuh a. Savitri, "Pentingnya Literasi Media Di Masyarakat," 2017. 
[9] S. Giraldo Luque and O. Paredes, "Study Assessment Criteria for Media Literacy Levels Study Assessment Criteria for Media Literacy Levels Final Report Final Report edited by EAVI for the European Commission Prepared for the European Commission Information Society and Media Directorate-Gen," no. October, 2009.

[10] G. R. Adiarsi, Y. Stellarosa, and M. W. Silaban, "Literasi Media Internet di Kalangan Mahasiswa," Humaniora, vol. 6, no. 4, p. 470, 2015, doi: 10.21512/humaniora.v6i4.3376.

[11] D.-T. victor Chen, J. Wu, and Y.-M. Wang, "Unpacking New Media Literacy," J. Syst. Cybern. Informatics, vol. 9, no. 2, pp. 84-88, 2011.

[12] B. Miočić and J. Perinić, "New media literacy skills of youth in Zadar," Medijska Istraz., vol. 20, no. 2, pp. 231-254, 2014.

[13] T.-B. Lin, J.-Y. Li, F. Deng, and L. Lee, "Understanding New Media Literacy: An Explorative Theoretical Framework,” J. Educ. Technol. Soc., vol. 16, no. 4, pp. 160-170, 2013. 